Article

\title{
Solutions Journalism: Strategies for Effecting and Managing Change
}

Mark Lowes and Sherry Devereaux Ferguson, University of Ottawa

\begin{abstract}
The field of journalism is undergoing epic changes at this time. With the growing impact of social media and citizen journalism, among other trends, traditional schools of journalism face a need to re-examine their most fundamental premises. Historically journalists adopted a code of practice whereby the ideal news article focused on issues and problems of consequence to society, and reporters presented both sides of the case. The gold standard was balanced reporting that investigated and uncovered abuses in society, with the mantra being "if it bleeds, it leads.". There was no added incentive or requirement to take responsibility for solving the problems they uncovered. While print media organizations faced a backlash of criticism following the era of "yellow journalism," they did not confront the necessity to reorient the entire profession; rather they simply had to "clean up their act" and operationalize what they already knew and believed. Today, the situation is dramatically different-largely as a consequence of the rise of citizen journalism, the impact of social media, and the trend toward an introspective look at their profession by journalists themselves and by those who train the journalists. In this article, we look at the emerging focus on a phenomenon called solutions journalism. Solutions journalism differs in both form and intent from not only the traditional standard of reporting, which focuses on problems, but also "good news reporting," which tends to be superficial and non-solution oriented. In an effort to understand the current push for a new direction in the journalism profession, we will look at the rise of the new paradigm, pioneers in solutions journalism, characteristics of solutions journalism, and the theoretical foundations of solutions journalism. In exploring the latter point, we will examine the relationships among solutions journalism, social media, open source, systems, and open innovation theories.
\end{abstract}

Keywords: solutions journalism, social media, open source, systems, open innovation. 
The field of journalism has been undergoing epic changes over the past decade. With the growing impact of social media and citizen journalism, among other trends, traditional schools of journalism face a need to re-examine their most fundamental premises. Historically journalists adopted a code of practice whereby the ideal news article focused on issues and problems of consequence to society, and reporters presented both sides of the case. The gold standard was balanced reporting that investigated and uncovered abuses in society, with the mantra being "if it bleeds, it leads" (Bornstein, cited in Lydersen, 2014). There was no added incentive or requirement to take responsibility for solving the problems they uncovered. While print media organizations faced a backlash of criticism following the era of "yellow journalism," they did not confront the necessity to reorient the entire profession; rather they simply had to "clean up their act" and operationalize what they already knew and believed. In 2020, the situation is dramatically different-largely as a consequence of the rise of citizen journalism, the impact of social media, and the trend toward an introspective look at their profession by journalists themselves and by those who train the journalists.

In this article we examine an emerging scholarly focus on the emerging practice of solutions journalism. Simply put, solutions journalism is news reporting focused on emerging responses to societal problems and substantial social concerns. At the heart of solutions journalism is a style of reporting in which journalists critically examine possible solutions to social problems. This is based on an assumption that a solutions news frame will encourage greater audience engagement (Wenzel et al., p. 653).

According to Bornstein $(2005,2008,2010)$, solutions journalism differs in both form and intent from not only the traditional standard of reporting, which focuses on problems, but also "good news reporting," which tends to be superficial and nonsolution oriented. In an effort to understand the current push for a new direction in the journalism profession, we will look at the rise of the new paradigm, pioneers in solutions journalism, characteristics of solutions journalism, and the theoretical foundations of solutions journalism. In exploring the latter point, we will examine the relationships among solutions journalism, social media, open source, systems, and open innovation theories.

In their survey of the emerging scholarly literature on the solutions journalism model, Lough and McIntyre (2019) note that scholars have also only recently begun to study solutions journalism's effects. They cite Curry and Hammond's (2014, p.585) study which conducted a quasi-experiment in which they found individuals who read solutions-based stories reported feeling more interested, optimistic and informed and more likely to share those stories than those who read conflict-based stories. While 
the findings of this study provide encouraging results as to the potential social benefits of solutions journalism, Lough and Mclntyre note that participants in quasiexperiments are not randomly assigned, and thus internal validity is threatened. In a true experiment, with random assignment of participants, results indicated less support of solutions journalism as found by Mclntyre (2017). However, Mclntyre's results did show solutions-based stories caused readers to report feeling more positive affect and more favorable attitudes toward the news article and toward a solution to the problem than did conflict-based stories. Mclntyre and Sobel (2017) conducted another experiment regarding solutions stories and found found consumers of a solution-based story reported more positive affect and greater behavioral intentions to read similar stories. In the same vein, Curry at al. (2016) found in an experiment and two field tests, that individuals who read solutions stories reported higher levels of selfefficacy and optimism and spent more time on the webpage than those who read nonsolutions stories.

\section{Characteristics of Solutions Journalism}

Aitamurto and Varma (2018) have made the important observation that that a long standing criticism of mainstream news is that it often focuses on problems, crises, and negativity, thus prompting concern from practitioners and scholars because a singular focus on negativity contributes to audiences becoming disillusioned and disinterested in civic issues. They further note that, in light of these concerns, solutions-oriented approaches in journalism have gained momentum in recent years. In Europe and the United States solutions journalism has emerged as a form of journalism that aims to create positive social impact (Mclntyre 2015) by informing people of issues and by suggesting specific, effective ways to resolve these issues. "Predicated on the possibility and desirability of social progress, solutions journalism focuses on initiatives that seek to engage - if not solve - broader societal problems across a spectrum of subject matter" (Aitamurto and Varma, 2018, p.695).

Against this background, a solutions approach to journalism seeks to go beyond the surface, to discover not only what is working, but why and how it is working - or not working (Curry, 2014). Solutions journalism is evidence-based and critical in nature. Journalists may structure their stories as puzzles to be solved or mysteries to be uncovered. For example, a story about a disaster such as the crash of AirAsia flight 8501 would focus on probing what happened and why and how it happened. The story would also explore avenues available to ensure that it never happens again. To qualify as solutions journalism, the story should empower the reader to engage in community dialogues and do more than think about problems (Lough and McIntyre, 2019; Mclntyre and Lough, 2019). In the case of the AirAsia crash, such a story might have 
reviewed the practices of airlines such as Qantas of Australia or WestJet of Canada, which have never experienced crashes despite operating high passenger volumes over many years. In other words, what characterizes an airline that has a zero fatality record and how does it differ from airlines such as Malaysia Airlines and AirAsia, which have experienced failures that cost great numbers of lives in recent months?

As noted earlier, traditional journalism typically seeks to expose problems without probing solutions. In the case of reporting on riots in Ferguson, Missouri, and New York City, television networks and newspapers sensationalized the coverage, focusing almost exclusively on provocative images of the protesters, along with sound bites where they expressed their frustrations; television news networks did almost nothing to explore ways to resolve and learn from the crisis. Had they exemplified solutions journalism, the reporters might have interviewed citizens and police officers in communities characterized by positive police-citizen relations. These interviews could have allowed the journalists to inform the concerned publics on the differences in policing practices in communities with fewer problems. This kind of informed reporting and changes in framing of the stories could have, in turn, allowed the journalists to contribute to positive new directions in policing and better community relations. Instead, many believe, based on the subsequent execution of police officers in New York City, that the reporting inflamed the issues and contributed to a deterioration of the already volatile and out-of-control situation. In the wake of the massacre of the Charlie Hebdo journalists and cartoonists, one CNN journalist reported that many Muslims are intermarrying with Christians and people of other faiths. She speculated that these interfaith marriages hold the promise of alleviating tensions, building bridges, and contributing to a greater tolerance of diversity in the years to come. She said, however, that journalistic coverage rarely mentions this trend, which holds promise for a more united world (CNN News, January 9, 2015).

To be credible, solutions journalism must be highly informative, accurate, and objective in its reporting. Solutions journalism does not involve advocacy or "proposing particular models, organizations or ideas, picking winners, or making suggestions to readers about what they should do to fix a problem" (Bornstein, 2011, p. 3). It does involve "great story telling," depicting characters who confront challenges, experiment with solutions, sometimes succeed and sometimes fail. When they fail, they try to figure out what happened in order not to repeat their mistakes. According to solutions journalism, we can learn as much from our failures as from our successes; so we need to explore all pathways. As noted on the Solutions Journalism Network, "Solutions journalism can include reporting on responses that are working, partially working, or not working at all, but producing useful insights" (Solutions Journalism Network, 2014, p. 1). In short, solutions journalism involves "deep dives, critical assessments, and 
compelling stories about the ideas, models, policies, organizations, and people working to solve our toughest problems" (Solutions Journalism Network, 2014, p. 2). Solutions journalism is not about hero worship (efforts to glorify individuals as opposed to focusing on their ideas), silver bullets (claims of quick and easy solutions), or afterthoughts (the offering of single paragraphs at the end of traditional news articles that give passing mention to stabs at problem solving) (Rosenberg, March 19, 2014).

Solutions journalism shies away from placing blame, which often stigmatizes those who are victims of abuse or crime (Lydersen, 2014). Inner city residents of communities characterized by violence, for example, can suffer the results of such coverage in a myriad of ways. They may lose taxes from businesses that choose to locate in areas perceived as "safer." Local real estate may go down in value. Residents may develop a lowered sense of self-esteem as a consequence of living in areas depicted as violent and crime-ridden.

Another characteristic of solutions journalism is that it is forward-looking, discussing ideas with "potential to grow" (Bornstein, 2011, p. 3). Despite the fact that solutions remain an "under-represented" component in news coverage, millions of organizations are tackling old problems in new ways:

[These organizations] are doing everything from protecting marine life, grasslands and forests, advancing rights and opportunities for women, gays and lesbians, disabled people and ethnic minorities, organizing to overthrow dictators, and inventing or restructuring institutions to deliver things like fresh water, health care, education, financial services and electricity to the world's poor. (Bornstein, 2011, p. 3)

Denmark has been hailed as a country that has moved against the historical trends, transitioning to a genre of journalism focused on identifying and publicizing possible solutions to societal problems. In accomplishing this end, they give voice to those who are most marginalized and encourage Danish citizens to develop "substantive, systemic solutions while using experts as citizen advisors" (Haas, 2003).

\section{The Emergence of a New Paradigm}

Historically, journalists have placed little focus on solution-oriented content in their coverage of societal problems. For example, a content analysis of 300 articles covering the issues of pollution, poverty, and incarceration (1995 to 2000) found that the news coverage did not specify causes, effects, or responsible parties for the problems (Kensicki, 2004). Moreover, the journalists rarely referenced non-profit government organizations or employed terms such as advocate or environmentalist, which might 
have encouraged action by individuals. Nor did the articles call for action by readers or promote the idea that the problems were solvable. In short, the researchers concluded that the nature of the coverage encouraged apathy, rather than individual or collective action, on the part of the readers (Kensicki, 2004). A study by the Engaging News Project of the Annette Strauss Institute for Civic Life at the University of Texas at Austin supported this conclusion (Curry, 2014). The latter study, which employed a sample of 755 American adults, concluded that readers of solutions journalism articles felt "more informed and interested" (p. 1) than non-solutions readers after reading a news article on a current problem. Study participants read stories on one of the following three issues: the effects of traumatic events on school children in the US, homelessness in urban centers in the US, or inadequate clothing among the poor in India.

Despite the failure of news organizations to implement solution-oriented journalistic coverage, some scholars have recognized the need to move against the historical trends. As early as 1990, for example, scholars such as Fraser (1990) attempted to apply theories of the public sphere, such as those developed by Habermas (1962), to journalistic coverage of the public sphere (Fraser, 1990). Fraser used a four-part critique of Habermas to suggest possible guidelines for journalism aimed at furthering public interests. This critique was applied, in one instance, to a Pulitzer prize-winning race relations campaign by the Akron Beacon of Ohio (Haas and Steiner, 2001). Scholars focused on the promotion of solutions journalism, however, argue for a distinction between public journalism, civic journalism, and solutions journalism. They say that solutions journalism is not a movement, but a simple tool that encourages reporters to tell a story that helps to clarify the nature of problems and to inform readers on the range of responses to the problems (Solutions Network, 2014).

In the same way, proponents of solutions journalism make a distinction between this genre and "good news" or "positive news" reporting. They say that good news stories celebrate heroic actions and the generosity of people. They inspire rather than inform the reader, creating a warm fuzzy feeling but accomplishing little in the way of tangible results. As freelance journalist Russ Baker noted, positive news stories have traditionally been rushed in the execution, written poorly, "saccharin" in tone, and formulaic (cited in Benesch, 1998). They often appear on holidays and weekends as a kind of light news offering. Some of the early efforts at solutions journalism (e.g., good news features on the Peter Jennings show during 1996 and 1997) failed when researchers and journalists were unable to identify enough stories with substantive content (Benesch, 1998). Solutions journalism, on the other hand, aims to address serious problems and produce observable results that make a difference in people's lives; it aims to bring new insights to the readers, who then have the opportunity to 
apply their learnings to problem solving. For instance, in 2014 the Engaging News Project and the Solutions Journalism Network released a joint report on the effects of solutions reporting demonstrating that, relative to problem-focused coverage, this form of journalism increases optimism, a sense of self-efficacy, and intentions to get involved in efforts to address the problem (cited Curry et al., 2016).

Solutions journalism also differs from citizen journalism. Citizen journalists achieve the highest level of visibility when they publish commentary on crises such as police shootings, riots, acts of terrorism, and natural disasters. The focus in these cases is most often on problems. Like the citizen journalist, the solutions journalist looks at current events and issues but from a different perspective. Instead of focusing on problems, the solutions journalist places his or her lens on solutions and acts as a transmitter of these ideas. The solutions journalist places their self as the node in a configuration of receivers, who provide the fodder for the stories. The citizen journalist goes in search of stories to report or accidentally stumbles upon them. While there can always be some overlap between functions, the differences are discernible.

\section{Pioneers in Solutions Journalism}

Publishing in the Columbia Journalism Review in 1998, Susan Benesch was one of the earliest academics to employ the term solutions journalism. The man most often credited with developing and promoting the concept, however, is David Bornstein $(2005,2008,2010)$, founder of Dowser.org and the Solutions Journalism Network. The term dowser comes from an instrument commonly referred to as a divining rod, used to identify the location of water. Bornstein's first book, The Price of a Dream: The Story of the Grameen Bank, chronicled the results of research spanning ten months in small villages in Bangladesh. This award-winning book placed second in the Harry Chapin Media Awards, made the finals in the Helen Bernstein New York Public Library Book Award competition for Excellence in Journalism, and found a place on the San Francisco Herald's list of best business books for 1996. Bornstein publishes actively on the topic of social entrepreneurship and innovation for the Atlantic Monthly and New York Times.

Bornstein's profile is notable because he is one of the few academics or journalists actively promoting the role of social entrepreneurship in effecting positive social change. According to Bornstein, any business person who is motivated by the idea of creating a better environment-alleviating poverty and disease, homelessness, or other problems-is as qualified as a non-profit worker to wear the mantle of social entrepreneur. He says it is the motivation behind the business or activity that decides where the effort falls on the scale of social entrepreneurship (Kawasaki, 2007). And by 
this reasoning, these businesses would have the same right as any non-profit organization to positive publicity.

In describing the raison d'être for Dowser.org, Bornstein states, "We're living through a global social change renaissance. Millions of people are building organizations and social enterprises, attacking problems with new ideas. But most of this activity is hidden. The news is much better at telling us what went wrong yesterday than what's being done to make tomorrow better" (GroAction, p. 5). Dowser aims to address this lack of balance by telling stories with a "solution frame," which describes how people create and operationalize their ideas. Dowser is interested in social innovators, no matter their age or level of experience. The organization plans to expand its operations from the United States and Canada to other countries in the world, covering any individual or organization (business, non-profit, or government) that demonstrates creativity in solving social problems. Their mantra is "positive change."

Bornstein, who now publishes a column called Fixes in the New York Times, says that positive change is occurring in the coverage of issues such as homelessness, rural poverty, and disparities in the health care and foster care systems as a result of the growing trend toward taking a more positive view of the news function. And a number of readers are beginning to share their efforts to effect change in their communities with the readers of Fixes. Pulitzer prize-winning Tina Rosenberg (December 11, 2014) recently wrote that the column Fixes had publicized the efforts of at least 60 individuals or organizations to find solutions to major world problems in 2014. The kinds of platforms publicized by the Solutions Journalism Network include Kickstarter, GiveForward, and Indie Voices (Dowser, 2014). Some efforts are successful, others less so.

A common strategy involves allowing less expert individuals to assume the tasks normally assumed by experts. Examples include "Reading Partners" in Charleston, Carolina, "Project Echo" in New Mexico, and "Strong Minds" in Kampala. With only six surgeons serving a country the size of Texas, Zambia is now licensing individuals with three years of surgical training to carry out the most common surgeries, and CNN recently featured a young woman who began to perform medical duties in the Ebola crisis even though she had no prior education in the medical or any other field. Individuals with two to four years of graduate training are now acting as dental therapists in rural communities in Alaska and Minnesota (Rosenberg, December 11, 2014). In a number of other states and countries, nurses with advanced training are undertaking some of the tasks traditionally performed by doctors. 
In India, volunteers with little training or education go house-to-house to administer a one-page test to children, designed to evaluate math and reading skills. "Springboard Collaborative" uses parents from low-income families (mostly Latino and African American) to assist with a summer reading program in Philadelphia. Nine million women in more than 40 African countries participate in savings programs that allow participants to draw funds as required from the cooperative pool. No banks or other outsiders are involved in the programs, which extend for years.

In most of these cases, the less trained professionals, workers, and volunteers live and work close to their client population (Rosenberg, December 11, 2014). Sociotechnical theory tells us that problems are best solved close to source (Jaques, 1951; Lawrence and Lorsch, 1967; Pasmore, Francis, Haldeman, and Shani, 1982; Rice, 1953, 1958; Trist, 1951; Woodward, 1965). These examples of creative solutions to community health and educational issues would seem to illustrate that point.

These trends are not without precedent. A classic example, which first appeared in the Harvard Business Review, recounted the story of a Tulane University professor training an uneducated janitor named Sweeney to take over the running of the Biomedical Computer Center. In subsequent, the janitor trained others to use the computers (Livingston, 2003). Quite beyond the need to fill a gap when expertise is in short supply, historical precedent also tells us that many of the most innovative ideas come from people working outside a particular field, because they are not constrained by the existing conventions and knowledge upon which those with more specialized expertise rely (Koestler, 1964). Nor does the delegation of tasks to non-specialists necessarily translate into second-class care. For example, hepatitis $\mathrm{C}$ patients in rural New Mexico who see local non-specialists fare better than those who see specialists in Albuquerque.

Readers of the Fixes column are sharing these ideas with others. One individual noted, for example, that she planned to share the column with local leaders. Another reader added that the column was a "welcome counterpoint" to the "we're-going-toHell-in-a-handbasket" discourse that typified news coverage of societal issues.

\section{Theoretical Foundations of Solutions Journalism}

The theoretical underpinnings of solutions journalism can be found in open source, open innovation, and open systems. The following discussion will explore the links between solutions journalism and these theories. 
Many see the information-sharing potential in social media as the driving force behind solutions journalism. According to Pew Research Internet statistics, 73\% of online adults have a social network profile, with Facebook and Instagram being the preferred platforms (71\% use Facebook). Over 42\% use multiple social network platforms, including Pinterest, Instagram, LinkedIn, and Twitter. Preferences for the different social platforms vary among demographic groups. For example, women in particular like Pinterest; college graduates like Linkedln; and younger adults, urban dwellers, and non-whites like Twitter and Instagram (Pew, 2013). In short, the statistics continue an upward climb, and many companies and governments are taking advantage of the potential in social media not only to publicize their products and provide services to the users, but also to access vast reserves of human intelligence.

The phenomenon of social media would not have been possible, however, without the development of Open Source Software (OSS). The term open source originated at a 1998 meeting of software strategists in Palo Alto, California (Still, 2010). Its formal adoption for use in the field of software development occurred several months later at a meeting of major freeware and open source project leaders convened by technology publisher Tim O'Reilly. The meeting acquired the label of the "Open Source Summit" (http://linuxgazette.net/issue28/rossum.html). Despite the overriding popularity and acceptance of the term open source, some choose to use the term FLOSS (FreeLibre and Open Source Software) in preference to OSS (Nash, 2010). Whatever the nomenclature, the idea remains the same.

Open source software allows a geographically dispersed community of Internet users to make contributions to its development. Fundamental to OSS is the accessibility of the source code to any user who would like to refine or extend the applications of the software, modify the material, or redistribute the output of these collaborations or resulting products (Gacek and Arief, 2004). As in the case of Linux, the users are the developers of the software; and the most dramatic advances in software development have occurred outside of the "traditional powerhouses" of Internet technologies. As Bers (2005) noted: "Email, the World-wide Web, Google, e-commerce, Linux, and eBay have emerged not from . . IBM, Intel, Bell Labs, or Microsoft, but from users of their technologies-business innovators, user groups, and communities of practice outside of the original centers of innovation" (p. 3).

Virtually all of the major sharing platforms-Facebook, Instagram, MySpace, YouTube, blogs, Twitter, Google, and Wikipedia - emerged from the development of open source software, which was itself the brain child of knowledge sharing. 


\section{Relationship between Open Source Theories and Open Innovation}

Over time, the term open source has come to connote a philosophy or a movement, which extends its influence into health, politics, science, business, media, and other areas (Haider and Kreps, 2004; Lewin and Zhong, 2013). Hundreds of thousands of articles now discuss the value of open source approaches that draw upon the collective intelligence in creating knowledge. Students at the University of Texas at Austin compete each year in the Dell Innovation Challenge, designed to find solutions to world problems. Citizens of Cairo, Egypt, participated in a project targeted at solving traffic safety and congestion issues. The General Mills World Innovation Network invites contributions for new product lines, solutions to technological problems, and improved online presence. IndieGoGo and Kickstarter provide examples of websites that solicit crowdfunding of innovative ideas (We THINQ, 2014). Large numbers of online communities contribute to Wikipedia, which has become a compendium of knowledge that makes encyclopedias obsolete. As suggested by the examples previously mentioned, the contributors to these open source initiatives range from students to scientists to hobbyists. Defined as the creation of content by large online communities, the term crowdsourcing is now applied to these kinds of open source initiatives.

According to Jeff Howe (2008), who coined the term, crowdsourcing refers to outsourcing a task (normally performed by employees) to a large but ill-defined community of Internet users. The request for contributions comes in the form of an open call, and the respondents may or may not receive compensation for their efforts. When given, compensation may be monetary or non-monetary in nature. Nonmonetary recognition may simply be the mention or introduction of top contributors on the organization's website (Antikainen and Väätäjä, 2009; Huberman, Romero, and Wu, 2009). Unlike Howe, others sometimes extend the idea of crowdsourcing to include uncoordinated, voluntary, and decentralized sharing of knowledge that may occur spontaneously among members of social networks (Hudson-Smith et al., 2009). The latter use a different term (crowdcasting) to refer to situations where intermediaries issue calls for engagement and offer some form of compensation. In other words, Hudson-Smith and colleagues apply the term crowdcasting to the phenomenon identified by Howe as crowdsourcing.

Whatever the preference in terminology, related practices involve the harvesting of information or knowledge from a largely anonymous community of stakeholders, and 75\% of respondents to a January 2010 survey by the Marketing Executives Networking Group (MENG) consider crowdsourcing or crowdcasting to be a "highly effective or effective approach for new product and service innovations" (Sullivan, 2010, p. 23). 
Within the world of management, the most frequent discussions of open source approaches such as crowdsourcing take place with regard to innovations, and the most often referenced figure is Henry Chesbrough. In a landmark book, Open Innovation: The New Imperative for Creating and Profiting from Technology, Chesbrough $(2003,2006)$ introduced a new organizational paradigm for thinking about innovations. This externally-focused paradigm shifted the emphasis from diffusion of innovations, a concept associated with Everett Rogers (2003), to knowledge creation. Open innovation theory asserts the importance of going outside the organization in a quest for new ideas - then pooling this knowledge with the ideas generated by internal research and development (RandD) units. Closed innovation, on the other hand, supports a culture that relies solely on the efforts of RandD and other internal groups. (See also Rass, Dumbach, Danzinger, Bullinger, and Moeslein, 2013.)

Christensen $(1997,2000)$ believes that the survival of many large firms depends on their ability to cope with disruptive or radical change, many of which come with Web 2 technologies. At the same time, he does not trust that sufficient knowledge to cope with these changes of an exponential nature reside within the walls of the organization. As a consequence, the survival and prosperity of the organizations depend on their capacity and willingness to capture intelligence outside their boundaries. As the workforce becomes more skilled, venture capital becomes more readily available, and outside suppliers demonstrate increased potential to meet company needs, open innovation arises as a practical option and a feasible solution to the lack of expertise within the firms. Chesbrough $(2003,2006)$ says that blind adherence to existing business models leads many companies to fail in their efforts to create and bring new inventions to the marketplace.

In support of these assertions, the fastest growing Inc. 500 companies are outperforming Fortune 500 firms (their larger counterparts) in implementing open source technologies (Barnes, 2010). This trend that suggests the larger firms may fear the uncertainties and potential risks that come with open source technologies and open innovation approaches. In fact, many governments and businesses are reticent to create, adopt, or even allow their employees to use these new technologies (Ranger, 2009; Kennedy, 2009; Bradley, 2008) - a hesitation that will almost certainly impede and delay the creation and adoption of novel ideas and solutions.

\section{Relationship between Open Innovation and Open Systems Theory}

In additional to reflecting open source theories, open innovation practices such as crowdsourcing draw heavily on open systems theory, which continues to have an 
impact on scholarship across the social and physical sciences. Yet open source approaches confirm the viability of the widely accepted open systems model. By system openness, we mean the extent to which a system exchanges information with its external environment, creating the potential to draw new ideas and energy into the system (Bertalanffy, 1950).

The first researchers to apply these ideas explicitly to organizations were Daniel Katz and Robert Kahn (1966), whose ideas appeared in The Social Psychology of Organizations. The Social Psychology of Organizations subsequently achieved the status of a classic in the field of sociology. Katz and Kahn credited Talcott Parsons (1937), in turn, with having been a critical influence in the development of their ideas (Rogers and Rogers, 1976).

Unlike closed systems, which experience ongoing deterioration or entropy, open systems exemplify and elevate the importance of (1) communication between and among the component parts of the system, (2) relational as opposed to individual concerns, (3) looking outside the organization for insights and information, (4) accepting the dynamic nature of organizations, (5) recognizing that multiple paths lead to any desired end (equifinality), and (6) maintaining open feedback loops to supply the organization with a continuing flow of information about the external environment. (See Ferguson and Ferguson, 1988, for a more complete discussion of the characteristics of open versus closed systems.)

Some of the points of correspondence between open innovation and open systems theory include the following:

First, the exchange of information among large numbers of users constitutes the essence of the open innovation movement, fulfilling a major characteristic of open systems theory - the elevation of communication to a role of critical importance.

Second, open innovation practices (as manifested in crowdsourcing and crowdfunding) involve a move from the individual to the relational. Social media rely on large networks of users or communities of practice to create and distribute content. Open innovation demands that organizations nurture and capitalize on these social networks. Rather than relying on the individual RandD worker or the lone leader to provide insights and knowledge, the open innovator calls upon large numbers of people to contribute to idea generation and problem-solving. Crowdsourcing engages potentially millions of online users of sharing technologies. Thus, the open source movement supports the second tenet of open systems theory-a move from an emphasis on the individual to a stress on the relational. 
Third, crowdsourcing and other open innovation practices assume that knowledge is widespread in the population - not restricted to a few individuals or large organizations. Thus, organizations look outside their boundaries for ideas, expertise, and people capable of bringing innovations to market (Castiaux, 2007). Sometimes they out license work, acquire the rights to intellectual property owned by others, or issue open calls for contributions from large numbers of stakeholders or even anonymous crowds. Thus, as advocated in open systems theory, open sourcing involves going outside the boundaries of the organization for insights and information.

Fourth, the open innovation movement assumes that organizations are in a constant state of flux. More specifically, theories related to disruptive and discontinuous change describe a contemporary environment where organizations can no longer depend on "incrementalism" to sustain their organizations. Whereas the old cyclical models saw short periods of innovative ferment, followed by long periods of incremental adjustments and stabilization, contemporary models see long periods of ferment followed by brief periods of adjustment (Bers, 2005). Radical change has become the norm in our social media environment. Thus, the open innovation movement reflects the fourth tenet of open systems theory-a recognition of organizations as dynamic entities.

Fifth, the open innovation movement assumes the viability of multiple pathways to knowledge. When organizations issue open calls for contributions, they assume they will obtain a multitude of responses, which (according to open innovation theory) they will combine with the knowledge already held in their research and development departments. As Nambisan and Sawhney (2007) observe, "There is no one right way to master this tool [network-centric innovation]. For instance, loosely governed community-based innovation projects are a very different animal from tightly-orchestrated development projects driven by a large firm." Social constructionist theories likewise see the real potential in the open source movement as the possibility to "recombine" and find new social uses for information (Bers, 2005). In other words, the open source movement well exemplifies the fifth tenet of open systems theory-the principle of equifinality.

Finally, the open innovation movement depends on a two-way flow of information with open feedback loops. A dominant characteristic of open innovation is the provision of feedback mechanisms that allow for critiques, questions, and comments. Both traditional media (TV, newspapers, magazines, and other print media) and social media (blogs, wikis, Twitter, Facebook, and other sharing platforms) both display or announce and publicize feedback options. Thus, the sixth tenet of open 
systems theory-the existence of open feedback loops-also characterizes open innovation. In short, the open innovation movement (characterized by practices such as crowdsourcing) displays all of the above characteristics of open systems theory.

\section{Relationship between Open Innovation and Solutions Journalism}

The overriding trend driving the momentum for solutions journalism is the need to innovate - the need to find new ways of tackling problems. This dilemma is exemplified by the events surrounding September 11, 2001. Prior to the hijacking and piloting of aircraft into the World Trade towers and the Pentagon, the airline industry had based its crisis management plans on an outdated paradigm - a paradigm that assumed hijackers would demand ransom and/or transport to another country in exchange for the safety of the passengers. They never imagined the hijackers would adopt the strategy taken by the Japanese in World War II and undertake a suicide mission. The word jhadist was only a dictionary term, which many North Americans would not have known. In the same way, no one ever assumed that an international people's tribunal would indict a president of the United States (George W. Bush) for treason. No one fathomed that protests against racist profiling would reach the point of closing down streets and highways on some of the largest American cities or that an armed gunman would gain access to the Parliament buildings in Ottawa. Change and protest are the operative words in political, social, and economic circles. In communication departments, change management has become a field of study. So while journalism has only recently seen the emergence of terms such as solutions journalism, other fields of communication have embraced the need to look for change strategies in a more timely fashion. To keep up with their transformed environment, journalists are being urged to adopt a new paradigm of reporting.

Some of the points of correspondence between open innovation and solutions journalism are the following.

First, a commitment to solutions journalism implies a commitment to informing the public on both problems and potential solutions. For that reason, communication has an all-important role to play. Through this communication, journalists act as recorders of ideas and publicists for those ideas and solutions. Through positive coverage, solutions journalism encourages a continuing dialogue. Participating as a reader in mainstream news coverage can be a painful experience, causing many to tune out (Tenore, 2014). As studies in fear appeals have often found, there are limits to the average person's tolerance for violent, threatening, and fear-mongering content (Ferguson, 1999; Bornstein, 2012). Cancer patients say that they rarely hear anything after the doctor says, "You have cancer" (Witte, 1992). A 2008 study by the Associated 
Press showed that young readers expressed a desire to "tune out" as a result of news experiences that resulted in high levels of stress and anxiety (cited in Bornstein, 2011, p. 2). According to the study, the answer to countering this trend is to find more innovative ways to deliver "compelling" and empowering news stories. In the same way, television viewers tune out if a Humane Society public service announcement becomes too graphic. Instead of encouraging communication and thoughtful consideration of possible solutions, negative coverage often has the opposite effectmaking people feel powerless and overwhelmed by the enormity of problems. Moreover, as Tenore (2014) notes, nothing is one-dimensional. Both good and bad exist in every picture. Solutions journalism aims to show the often obscured part of the picture, to empower the reader, and to present options for action.

Second, solutions journalism involves a move from the individual to the relational. Traditionally, the investigative journalist, news reporter, or feature writer acted on his or her own to conduct research, interview sources, and make personal judgments about those ideas worth conveying to the public. In the traditional model, columnists and editors take stances on issues, and even news reporters sometimes assume the mantle of advocate in promoting some causes over others. The promotion may be subtle or not so subtle, as in the case of Fox News. The solutions journalist does not seek, on the other hand, to argue a given point of view. Instead he or she exposes the facts (both problems and options for solutions) and invites readers to contribute to the discussion.

Third, solutions journalism relies on a population of contributors (users of social media, television viewers, and readers of print media), who operate largely outside the boundaries of the organization. Rather than going to experts within organizations, solutions journalists identify sources that may have ideas but not necessarily any formal credentials or expertise to propose solutions to problems. They could be students, engineers, salespeople, nurses, or stay-at-home moms. Thus, as noted in the earlier examples, solutions journalism moves the discussion from a focus on the views of experts in a given field to the collective knowledge that resides outside the organization. The underlying assumption is that knowledge is widespread in organizations and society. Traditionally, journalists have been careful to vet their sources and confirm the qualifications of the sources to speak on a particular economic, social, or scientific issue. The viewpoints of "lay" individuals only appear in the press when they are reacting to some newsworthy event or happening or when they become the subject of a feature story (e.g., the heroic individual who hid the hostages at the kosher grocery store in the recent Paris massacres). 
Fourth, solutions journalism assumes that societies are in a constant state of transition. It dismisses the idea that today's problems are embedded in and firmly attached to our future. According to this view, solutions are always within our reach if we deploy enough resources to effect changes. The assumption is that the future canand will-look very different from the present. Scholars such as Bornstein speak of enormous global power shifts taking place at the moment, with the rise of the "citizen sector" and exponential increases in the number of individuals, communities, and organizations pursuing social change (Bornstein, 2011, p. 3). According to Paul Hawkin (cited in Bornstein, 2011), we are experiencing the "largest movement the world has ever seen" (p. 4). Journalism holds the potential to help societies to "self-correct" (Bornstein, p. 4), identifying and implementing changes that can make the world a more positive place in which to exist. In that sense, solutions journalism also has a social justice dimension (Lydersen, 2014).

Fifth, like the open innovation movement as a whole, solutions journalists believe in the viability of multiple pathways to knowledge. The rejection of advocacy for any one position or solution implies a commitment to publicizing all points of view. That perspective, in turn, implies recognition of the possibility that more than one solution could work. The problem of homelessness may have many roots: social, economic, or cultural, for example. But even within one category such as economic, many different variables can be at play. The root causes could be mental illness, loss of employment, or problems with alcoholism or drugs. No one solution would solve all of the issues connected with homelessness. So publicizing different approaches, in line with the basic premises of solutions, journalism, makes sense.

Sixth, solutions journalism (like other open innovation approaches) relies on a two-way flow of information with open feedback loops, a concept first associated with Shannon and Weaver. These feedback loops provide the opportunity for change to occur: "Behavioral psychologists tell us that feedback is likely to lead to desired changes when it draws attention to possibilities, connects with people's aspirations, and provides road maps. Feedback that is strengths-based also tends to be more effective than feedback that is deficit-based" (Bornstein, 2012, p. 2). According to Wikinomics, mass collaboration has the power to effect change of enormous proportions (Tapscott and Williams, 2006).

\section{Conclusion}

In an environment where the old paradigms have failed, innovation acquires a high value and the communication technologies undergirding innovation become critical organizational resources. In this environment, the users of Facebook, Instagram, 
Twitter, Skype, blogs, wikis, Second Life, YouTube, Flickr, mobile technologies, LinkedIn, and other sharing platforms constitute the social capital of an information society (Bourdieu, 1986; Coleman, 1988; Frank, Zhao, and Borman, 2004; Mandarano, Meenar, and Steins, 2010); and practices such as crowdsourcing enable innovating organizations to access this social capital (Antikainen, Mäkipää, and Ahonen, 2010; Brabham, 2013; Ekins and Williams, 2010; Putnam, 2002; Seltzer and Mahmoudi, 2012).

The possibilities for stories that are solution-oriented are endless. Stories on the economy, for example, could benefit from solutions-oriented discussions. The stock market is highly responsive to downturns in public confidence, and stories focused on problems tend to contribute to this lack of confidence. A different focuson solutions-could change the environment to a more positive one, which breeds confidence in society's ability to cope in volatile circumstances. In the same way, many stories that talk about the drug problem, religious intolerance, and other societal issues could be reframed to focus on what some people are doing to address the problems. Social and economic factors often underlie health and educational issues. Solutions journalism holds the potential to expose the real determinants and, through sharing this increased knowledge, to contribute to long-lasting answers to problems that are masquerading under other labels. Solutions journalism does not focus on blame, which stereotypes and pigeonholes communities and individuals already suffering from numerous societal ills. Finally, solutions journalism is also economically viable in a period of time when few news organizations have the financial resources to invest in research. Solutions journalism draws on resources that are readily available.

\section{Bibliography}

Aitamurto, T. and Varma, A. (2018). The Constructive Role of Journalism. Journalism Practice, 12 (6), 695-713.

Antikainen, M., Mäkipää, M., and Ahonen, M. (2010). Motivating and supporting collaboration in open innovation. European Journal of Innovation Management, 13 (1), 100-119.

Antikainen, M. J., and Väätäjä, H. K. (2010). Rewarding in open innovation communities - How to motivate members? International Journal of Entrepreneurship and Innovation Management, 11, 440-456.

Barnes, N. G. (2010). Tweeting and blogging to the top. Marketing Research, 22, 8-13. 
Beaujon, A. (February 19, 2014). "Journalism Education Site Hopes to Become Hub for 'Solutions Journalism,'" accessed at http://www.poynter.org/news/mediawire/240343/journalism-education-sitehopes-to-become-hub-for-solutions-journalism/ on January 15, 2015.

Benesch, S. The rise of solutions journalism. Columbia Journalism Review 36 (6), 36-39.

Bers, J.A. (2005). Contributions of social constructionism to a theory of accelerated radical innovation. Retrieved from http://ariinstitute.com/_pdfs/publications/.

Bertalanffy, L. von (1950). The theory of open systems in physics and biology. Science, $111,23-29$.

Bornstein, D. (2005). The price of a dream: The story of the Grameen bank. New York, NY: Simon and Schuster.

Bornstein, D. (2008). How to change the world: Social entrepreneurs and the power of new ideas. New York, NY: Oxford University Press.

Bornstein, D. (December 20, 2011). "Why Solutions Journalism Matters, Too," accessed at http://opinionator.blogs.nytimes.com/2011/12/20/why-solutionsjournalism-matters-too/? $r=0$ on July 23, 2014.

Bornstein, D. (January 29, 2012). "Up for Debate: Why We Need Solutions Journalism," accessed at January 6, 2015.

Bornstein, D., and Davis, S. (2010). Social entrepreneurship: What everyone needs to know. New York, NY: Oxford University Press.

Bourdieu, P. (1986). The forms of capital. In J.G. Richardson (Ed.), Handbook of theory and research for the sociology of education. New York, NY: Greenwood Press.

Bradley, P. (2008). A selection of social media search engines. Ariadne, no.57, 40. Retrieved May 15, 2010 from http://www.ariadne.ac.uk/issue57/searchengines/.

Castiaux, A. (2007). Radical innovation in established organizations: being a knowledge predator. Journal of Engineering and Technology Management, 24, 36-52. 
Changemaker Showcase. (November 26, 2013). "Solutions Journalism: Covering Social Innovation," accessed at http://changemakershowcase.org/event/solutionsjournalism/ on January 13, 2015.

Chesbrough, H. (2003). Open innovation: The new imperative for creating and profiting from technology. Boston, MA: Harvard University Press.

Chesbrough, H.W. (2006). Open innovation: a new paradigm for understanding industrial innovation", in H.W. Chesbrough, W. Vanhanverbeke, and J. West, (eds.), Open innovation: Researching a new paradigm, pp. 1-12. Oxford: Oxford University Press.

Christensen, C.M. (1997). The innovator's dilemma: When new technologies cause great firms to fail. Cambridge, MA: Harvard Business School Press.

Christensen, C. M., and Overdorf, M. (2000). Meeting the challenge of disruptive change. Harvard Business Review, 78, 66-76.

Coleman, J.S. (1988). Social capital in the creation of human capital. American Journal of Sociology, 94, 95-120.

Culver, K.B. (February 19, 2014). "Taking Action: EdShift Launches to Move Journalism Education Forward," accessed at http://www.pbs.org/mediashift/2014/02/taking-action-edshift-launches-tomove-journalism-education-forward/ on January 16, 2015.

Curry, A., Stroud, N.J. and Stroud, McGregor, S. (2016). "Solutions Journalism and News Engagement," accessed at https://mediaengagement.org/wpcontent/uploads/2016/03/ENP-Solutions-Journalism-News-Engagement/ on July 18, 2018.

Curry, A. (2014). Engaging News Project on Solutions Journalism by the Annette Strauss Institute for Civic Life," the University of Texas at Austin, accessed at http://engagingnewsproject.org/research/solutions-journalism/ on January 17, 2015.

Dowser (May 1, 2014). "Who's Changing What and How: Spreading Solutions Journalism," accessed at http://dowser.org/spreading-solutions-journalism/ on January 17, 2015. 
Dugan, M., and Smith, A. (December 30, 2013). Pew Research Internet Project, accessed at http://www.pewinternet.org/2013/12/30/methods-22/ on January 11, 2015.

Ekins, S., and Williams, A.J. (2010). Reaching out to collaborators: crowdsourcing for pharmaceutical research. Pharmaceutical Research, 27, 393-395.

Ferguson, S.D. (1999). Communication planning: An integrated approach. Thousand Oaks, CA: Sage.

Ferguson, S.D., and Ferguson, S. (1988). Organizational communication ( $2^{\text {nd }}$ ed.). New Brunswick, NJ: Transaction Publishers.

Frank, K. A., Zhao, Y., and Borman, K. (2004). Social capital and the diffusion of innovations within organizations: the case of computer technology in schools. Sociology of Education, 77, 148-171.

Fraser, N. (1990). Rethinking the public sphere: A contribution to the critique of actually existing democracy. Social Text, 25, 56-80, doi:10.2307/466240, JSTOR $\underline{466240 .}$.

Gacek, C., and Arief, B. (2004). The many meanings of open source. IEEE, 21, 34-40.

GroAction. (2012). "The Future of News Media is Solution Journalism - David Bornstein of Dowser.org," http://vimeo.com/27240227, p. 5, accessed on January 6, 2015.

Haas, T. (2003). Importing journalistic ideals and practices? The case of public journalism in Denmark. The International Journal of Press/Politics, 8, 90-103.

Haas, T., and Steiner, L. (2001). Public journalism as a journalism of publics: Implications of the Habermas-Fraser debate for public journalism. Journalism, 2, 123-147.

Habermas, J. (1962). The structural transformation of the public sphere: An inquiry into a category of bourgeois society, trans. by T. Burger, 1989. Cambridge MA: The MIT Press.

Haider, M., and Kreps, G. L. (2004). Forty years of diffusion of innovations: utility and value in public health. Journal of Health Communication, 9, 3-11. 
Howe, J. (2008). Crowdsourcing: Why the power of the crowd is driving the future of business. New York, NY: Crown Business.

Huberman, B. A., Romero, D. M., and Wu, F. (2009). Crowdsourcing, attention and productivity. Journal of Information Science, 35, 758-765.

Hudson-Smith, A., Batty, M., Crooks, A., and Milton, R. (2009). Mapping for the masses: accessing Web 2.0 through crowdsourcing. Social Science Computer Review, $27,524-538$.

Jaques, E. (1951). The Changing Culture of a Factory: A Study of Authority and Participation in an Industrial Setting. London: Tavistock Publications.

Katz, D., and Kahn, R.L. (1966). The social psychology of organizations. New York, NY: John Wiley.

Kawasaki, G. (September 17, 2007). "Social Entrepreneurship: Ten Questions with David Bornstein," accessed at http://blog.guykawasaki.com/2007/09/socialentrepre.htm|\#ixzz3OFjc0mnD on January 11, 2015.

Kelly, J.E. (1978). A reappraisal of sociotechnical systems theory. Human Relations, 31, 1069-1099.

Kennedy, S. D. (2009). Social networking. Information Today, 26, 15-16.

Kensicki, L.J. (2004). No cure for what ails US: The media-constructed disconnect between societal problems and possible solutions, Journalism and Mass Communication Quarterly, 81, 53-73.

Koestler, A. (1964). The act of creation. New York, NY: Penguin Books.

Lawrence, P.R., and Lorsch, J.W. (1967). Differentiation and integration in complex organizations. Administrative Science Quarterly, 12, 1-47.

Lennox Gazette, accessed at http://linuxgazette.net/issue28/rossum.html.

Lewin, A.Y, and Zhong, X. (2013). The evolving diaspora of talent: A perspective on trends and implications for sourcing science and engineering work. Journal of International Management, 19, 6-10. 
Livingston, J.S. (September-October 1988). Pygmalion in management. Harvard Business Review. Reprinted as an HBR classic with a retrospective comment in 2003.

Lough, K., and McIntyre, K. (2019). "Visualizing the solution: An analysis of the images that accompany solutions-oriented news stories," Journalism, 20 (4), 583-599.

Lough, K., and McIntyre, K. (no date). "Journalists' perceptions of solutions journalism and its place in the field," accessed at http://isoj.org/research/journalists-perceptions-of-solutions-journalism-andits-place-in-the-field/ accessed on July 13, 2018.

Lydersen, K. (October 20, 2014). "Solutions Journalism for Social Justice," Social Justice News Nexus, accessed at http://sjnnchicago.org/category/blog/page/2/ on January 17, 2015.

Mandarano, L., Meenar, M., and Steins, C. (2010). Building social capital in the digital age of civic engagement. Journal of Planning Literature, 25, 123-135.

Mclntyre, K., and Lough, K. (2019). Toward a clearer conceptualization and operationalization of solutions journalism. Journalism, 1-16.

Mclntyre, K (2017) Constructive journalism: The effects of including solution information in news stories about social problems. Journalism Practice. Prepublished Dec 14, 2017. DOI: 10.1080/17512786.2017.1409647.

Mclntyre, K., and Sobel, M. (2017) Motivating news audiences: Shock them or provide them with solution? Communication and Society 30 (1), 39-56.

Mclntyre, K (2017) Constructive journalism: The effects of including solution information in news stories about social problems. Journalism Practice. Prepublished Dec 14, 2017, DOI: 10.1080/17512786.2017.1409647.

Mclntyre, K, Sobel, M (2017) Motivating news audiences: Shock them or provide them with solution? Communication \& Society 30 (1), 39-56.

Nambisan, S., and Sawhney, S. (2010). The global brain. Upper Saddle River, NJ: Wharton School Publishing. 
Nash, J.C. (2010). Directions for open source software over the next decade. Futures, $42,427-433$.

Neyer, A.-K., Bullinger, A.C., and Moeslein, K.M. (2009). Integrating inside and outside innovators: a sociotechnical systems perspective. RandD Management, 39, 410-419.

Parsons, T. (1937). The structure of social action. New York: McGraw Hill.

Pasmore, W.A., and Khalsa, G.S. (1993). The contributions of Eric Trist to the social engagement of social science. Academy of Management Review, 18, 546-569.

Putnam, R. D. (Ed.). (2002). Democracies in flux: The evolution of social capital. New York, NY: Oxford University Press.

Ranger, J. (2009). Exploring the potential of social media as organizational communication tools. Unpublished M.A. thesis, University of Ottawa.

Rass, M., Dumbach, M., Danzinger, F., Bullinger, A.C., and Moeslein, K.M. (2013). Open innovation and firm performance: The mediating role of social capital. Creativity and Innovation Management, 22 (2): 177-194.

Rice, A.K. (1953). Productivity and social organization in an Indian weaving shed. Human Relations, 6, 297-329.

Rice, A.K. (1958). Productivity and social organization: The Ahmedabad experiment. London: Tavistock Publications.

Rogers, E. (2003). Diffusion of innovations ( $5^{\text {th }}$ ed.). New York, NY: Free Press.

Rogers, E.M., and Agarwala-Rogers, R. (1976). Communication in Organizations. New York, NY: Free Press.

Rosenberg, T. (December 11, 2014). "Big Ideas for Social Change, 2014," accessed at http://opinionator.blogs.nytimes.com/2014/12/11/big-ideas-in-social-change2014/? r=0 on January 11, 2015. 
Rosenberg, T. (March 19, 2014). "What if Journalists Covered Solutions as Rigorously as They Covered Problems?" accessed at http://ivoh.org/journalists-coveredsolutions-just-rigorously-covered-problems/ on January 7, 2015.

Russo-Spena, T., and Mele, C. (2012) Five Co's in innovating: A practice-based view. Journal of Service Management, 23, 527-553.

Seltzer, E., and Mahmoudi, D. (2012). Citizen participation, open innovation, and crowdsourcing: Challenges and opportunities for planning. Journal of Planning Literature, 28, 3-18.

Semiocast. (2013). Twitter reaches half a billion accounts. Accessed at http://semiocast.com/en/publications/2012 0730 Twitter reaches half a billion accounts 140m in the US on August 10, 2013.

Still, B. (2010). A dozen years after Open Source's 1998 birth, it's time for OpenTechCom." Journal of Technical Writing and Communication, 40, 219-228.

Sullivan, E. A. (2010). A group effort: more companies are turning to the wisdom of the crowd to find ways to innovate. Marketing News, 44, 23-30.

Solutions Journalism Network, "Ethics and Financing," 2015, accessed at http://solutionsjournalism.org/about/solutions-journalism on January 15 , 2015.

Solutions Journalism Network, "Team," 2015, accessed at http://solutionsjournalism.org/about/solutions-journalism on January 11 , 2015.

Solutions Journalism Network, "What is Solutions Journalism?" accessed at http://solutionsjournalism.org/about/solutions-journalism-what-it-is-andwhat-it-is-not/ on March 22, 2014.

Tapscott, D., and Williams, A.J. (2006). Wikinomics: How mass collaboration changes everything. New York, NY. 
Tenore, M.J. (September 8, 2014). "How Media Practitioners Can Paint a More Accurate Picture of the World," Images and Voices of Hope (IVOH), accessed at http://ivoh.org/media-practitioners-can-paint-accurate-picture-world/ on January 17, 2015.

Trist, E.L., and Bamforth, K. (1951). Some social and psychological consequences of the longwall method of coal-getting. Human Relations, 4, 3-39.

We THINQ, Blog, "36 Great Examples of Crowdsourcing," November 20, 2014, accessed at https://www.wethinq.com/en/blog/2014/08/12/39-GreatCrowdsourcing-Examples.html) on January 11, 2015.

Wenzel, A., Gerson, D., Moreno, E., Son, Minhee, and Hawkins, B.M. (2018). Engaging stigmatized communities through solutions journalism: Residents of South Los Angeles respond. Journalism, 19 (5), 649-667.

Woodward, J. (1965). Industrial organization: Theory and practice. London: Oxford University Press.

Zephoria, "The Top 20 Valuable Facebook Statistics - Updated October 2014," accessed at https://zephoria.com/social-media/top-15-valuable-facebookstatistics/ on January 11, 2015. 